\title{
Rainfall and weather conditions inducing intense landslide activity in northern Spain (Deba, Guipúzcoa)
}

\author{
Victoria Rivas $^{1}$, Juan Remondo ${ }^{2}$, Jaime Bonachea ${ }^{2}$ and Javier Sánchez-Espeso ${ }^{3}$ \\ ${ }^{1}$ Dpto. de Geografía, Urbanismo y Ordenación del Territorio, Universidad de Cantabria \\ $5 \quad{ }^{2}$ Dpto. de Ciencias de la Tierra y Física de la Materia Condensada, Universidad de Cantabria \\ ${ }^{3}$ Dpto. de Ingeniería Geográfica y Técnicas de Expresión Gráfica, Universidad de Cantabria \\ Correspondence to: Jaime Bonachea (jaime.bonachea@unican.es)
}

\begin{abstract}
The Deba area is intensely affected by frequent shallow landslides triggered by rainfall. Relationships between rainfall and landslides in northern Spain, particularly for rainfall events driving multiple movements simultaneously, have not

10 been explored in depth so far. This contribution explores the role of rainfall in landslide activity during a quite long time span, (60 years), from a large network of rainfall gauges and a complete inventory of landslides, and utilizing three different strategies of analysis. 1,180 landslides have been inventoried, and 3,241 rainfall episodes automatically recognized and characterized in terms of rainfall amount, duration and intensity. Antecedent rainfall has also been considered. Six episodes of intense rainfall, which have produced multiple landslides ( $>50 \%$ of the recent past occurrences) have been identified. The

15 analysis provides different results: the extraordinary character of the triggering rainfall has been assessed, the meteorological conditions associated to those extreme episodes have been recognized and empirical rainfall threshold producing multiple landslides has been found ( $\mathrm{I}=7.7 \mathrm{D}-0.428$ ) and compared with others described in literature. Results show that multiple landslide occurrences are triggered by extreme convective rainfall, intense, short and with limited horizontal extent, as well as a marked summer-autumn seasonality, characteristic of Mediterranean climate.
\end{abstract}

\section{Introduction}

Landslide hazard assessment must be based on a detailed knowledge of the triggering factors: snow melting, river or marine basal erosion, seismic activity, rainfall or human intervention. However, rainfall-induced landslides are the most widespread phenomena, especially in mountain areas. In this type of movements, the occurrence depends on the response to water of the terrain materials (Corominas and Moya, 1999; Crozier, 1999; Corominas, 2001; Peruccacci et al., 2012, 2017). The role of

25 rainfall acquires special relevance in extraordinary episodes capable of producing numerous landslides simultaneously (Crozier, 2005).

There is a large number of references in the literature aimed at finding relationships between rainfall and landslides, especially regarding the determination of a critical rainfall threshold. That is, a minimum value of rainfall (although the soil moisture or hydrological conditions can be also taken into consideration) beyond which landslides have occurred in the past, and therefore 
30 are likely to do in the future (Reichenbach et al., 1998; Crozier, 1999; Aleotti, 2004; Martelloni et al., 2012; Palladino et al., 2018).

The methods based on empirical observations are focused on the statistical analysis of the relationship between rainfall and landslides. That is, on the identification and characterisation of specific rainfall episodes that, due to their exceptional character, have led to produce landslides. These methods provide thresholds based on different rainfall parameters: total volume, intensity, duration, or combinations of them, such as the typical intensity-duration (I-D) threshold, widely used for shallow landslides. Global thresholds were proposed initially by Caine (1980) from worldwide landslide occurrences. More recently, a broad list of thresholds, obtained from a review of the literature, is provided by Guzzetti et al. (2007, 2008). Most of them are obtained for specific regions, normally in large areas, with numerous landslides occurred on precise and well-known dates. Representative thresholds are not so common when dealing with small areas with a reduced number of instability events and not all accurately dated.

In a recent review, Segoni et al. (2018) analyse the main drawbacks of the rainfall thresholds published in the last decade. They highlight that a) only few works deal with long and complete datasets, b) the exact moment of the occurrence is frequently uncertain, and c) rainfall data often derives from a scarce rain gauge network density and limited to daily data. This is a fairly common situation worldwide, and hence these kind of analyses in areas with data limitations and uncertainties deserves to be explored. In the municipality of Deba (Guipúzcoa, northern Spain), there is an unusually long and complete landslide inventory for the recent past (last 60 years), whose spatial distribution has been analysed in previous works (Remondo et al., 2003a, b, 2005; Bonachea et al., 2009). Also, a good number of rain gauge stations, with appropriate length and high quality, is available. This information, although with limitations, provides a great opportunity to carry out a robust assessment of the characteristics of the rainfall capable of producing intense landslide activity in this area. This is particularly relevant taking into account that

50 in Cantabrian Mountains, where landslides are a common and widespread geomorphic process, only a few works related to rainfall induced landslides have been carried out (mainly Remondo et al., 2017; Valenzuela et al., 2017a).

In this context, the main objective of this work is to determine the rainfall conditions that are likely to produce slope movements in the area, and especially, the events producing multiple shallow landslides on natural slopes. The reconstruction of the past landslide occurrence entails the identification of the major rainfall episodes that have caused multiple landslides, as well as the

55 estimation of the exceptional magnitude of them. In order to improve predictions, a tentative site-specific empirical threshold is obtained and compared with others from similar geomorphic and environmental settings. Furthermore, spatial patterns of the rainfall and the weather conditions and seasonality associated to these extreme rainfall episodes are investigated.

\section{Study area}

This work has been carried out in the municipality of Deba, in north-western Guipúzcoa (Basque Country, N Spain) (Fig. 1), 60 with an extension of about $50 \mathrm{~km}^{2}$. Shallow landslides are widely distributed on natural slopes, affecting a significant extension of the study area. Most of the area is constituted by flysch facies, lutite, marl and limestone, with well-developed surficial 
formations. The relief is strong, with heights between 0 and almost $900 \mathrm{~m}$ a.m.s.l. and average slope gradient of $27^{\circ}$. There are narrow valleys, delimited by rectilinear slopes, and a coastline characterised by steep cliffs. Vegetation cover is quite continuous and consists mainly of cultivated prairies and pine trees. Climate is mild and humid, and corresponds to temperate oceanic type of Köppen classification (Cfb). Annual rainfall is around 1,500 mm, with low interannual variability. The monthly rainfall distribution displays an unmarked seasonal cycle, without summer drought. The maximum values occur in winter and autumn linked to frontal disturbances; during summer, the Azores anticyclone produces drier conditions, although episodes of intense rain are relatively frequent in this season.

\section{Material and methods}

\subsection{Landslide inventory}

The inventory of landslides (multi-temporal and event-based) includes a total of 1,180 movements (Table 1) identified and dated primarly through interpretation of aerial photographs and orthophotos and fieldwork, covering a 60-year period (Remondo et al., 2003b, 2008, 2017; Bonachea et al., 2009; Rivas et al., 2016). Landslides correspond mainly to debris slides, of small size ( $\approx 500 \mathrm{~m} 2$ and $200 \mathrm{~m} 3$ ), affecting weathered and colluvial materials. The contact between soil, about $0.5-1 \mathrm{~m}$ of thickness, and bedrock constitutes the rupture zone, usually parallel to the land surface. Debris slides often turn into debris flows, particularly when regolith is thick or water presence is important (Remondo et al., 2003b). All of them correspond to movements on natural slopes. Identified movements have been assigned to 21 time intervals. It has been possible to discriminate 3 types of situations with differentiated activity (Table 1):

- No Landslides: periods in which there have been only a few small landslides (<4/year) or not movement at all.

- Multiple landslides: periods in which abundant landslides, distributed throughout the study area, have occurred simultaneously. They might be classified as MORLE (Multiple-Occurrence Regional Landslide Events), as defined by Crozier (2005) for large areas. It is worth noting that the study area constitutes a small window of observation of a phenomenon extended over a wider area, and then with a regional relevance. Consequently, the number of landslides inventoried in each one of these periods is just a minimum sample of all those triggered by an unique episode of rainfall. There are 6 landsliding

85 events responsible of 688 movements, more than $50 \%$ of the total inventoried for the last 60 years. The assignation of precise dates of these 6 events has been carried out on the basis of different information sources: aerial photographs, post-event field surveys, technical reports of public agencies, regional newspapers, research papers, applications for indemnities to insurance companies and personal communication of neighbours.

- Undetermined: periods in which landslides have occurred, but the date is unknown and therefore can not be attributed

90 to any specific rainfall episode. Most of them were produced through long intervals for which no specific trigger evidence exists. 


\subsection{Rainfall data and procedure}

The rainfall data over the considered period (1953-2015) have been obtained from 15 meteorological stations (Fig. 1) with the most reliable records available, selected on the basis of length, completeness and quality. The rainfall data include 127,567 daily records; hourly ones are available only for a few stations and for recent times.

The selected stations provide a reasonable spatial representativeness of all the environmental conditions in the study area, but show a considerable data variability (up to $200 \mathrm{~mm}$ in a rainfall episode). This variability derives from the importance of local atmospheric conditions on intense rainfall. To solve this problem, the spatial distribution of rainfall was estimated with 22,614 daily rainfall models (number of days within the period studied) obtained by interpolation from all gauges, applying the inverse distance weighting method (IDW, exponent 2 and a cell size of $100 \mathrm{~m}$ ). Once these daily rainfall models obtained, the following strategies have been developed to characterize the rainfall events that have triggered the inventoried landslides:

a) Automatic determination of rainfall episodes for a central point, defined as the centroid of all the inventoried landslides (Fig. 2). Total daily rainfall data for this point was extracted from the daily models previously obtained. Subsequently, all the rainfall episodes were automatically computed. Each episode was individualized as a sets of days with continuous rainfall higher than $0.1 \mathrm{~mm}$. As a result, from 1953 to 2015, 3,241 rain episodes were automatically identified and characterized in terms of 1) duration; 2) average daily rainfall; 3) cumulative rainfall during the episode; 4) average daily rainfall intensity of the whole episode.

b) Accumulated rainfall for the central point. On the basis of total daily rainfall data in the central point, the amount of previous days was aggregated to each day, that is, accumulating the rainfall of the antecedent days. The number of days to be considered depends on the characteristics of the terrain and climate, which may vary widely depending on the local settings (Wieczorek, 1987; Crozier, 1999; Glade et al., 2000; Aleotti, 2004; Guzzetti et al., 2007; Li et al., 2011; Zêzere et al., 2015; Garcia-Urquía, 2016; Ma et al., 2016). For shallow landslides in slopes covered by permeable colluvium, where the interstitial pressure dissipates rapidly, the antecedent rainfall is not so important, since the rainfall itself generates the hydrological conditions required for instability (Mateos et al., 2012). Still, the antecedent rainfall is usually considered in this type of investigations. As a result, more than $6.33 \times 10^{5}$ records of accumulated rainfall were computed, from one single day up to periods of 28 continuous days.

c) Determination of rainfall episodes at each landslide location by interpolation. From the 22,614 daily rainfall spatial distribution models, the daily rainfall was extracted at the precise points where known date landslides (688 movements) were triggered. Thus, more than twenty thousand of rainfall for each landslide were obtained. Then, rainfall episodes that triggered each landslide were automatically computed, resulting 688 pairs of data (rainfall amount and duration). However, since the evidences obtained from scientific and press reports post-event (see below) reveal that such episodes were much shorter in time and much greater in intensity than those obtained automatically, filtering of data have been applied. In fact, automatically computed rainfall episodes show, in general, a few days of intense rainfall, preceded or continued by insignificant amounts of rainfall. In this context, instead of considering the entire rainfall episode, only the period in which the movements were really 
triggered was used. In other words, the rainfall episodes have been adjusted to obtain values closer to reality, unattainable by automatic treatment.

These proposed procedures represent identical treatments for all episodes of rainfall, providing representative data for each rainfall episode, in which the error will be equivalent in all cases.

130 From these landslide and rainfall data, it has been possible to carry out a quantitative characterization of the rainfall episodes driving multiple landslides (total rainfall, antecedent rainfall, intensity-duration thresholds) and typify their associated meteorological conditions.

\section{Results and discussion}

The instability in Deba area is characterised by an unequal distribution of landslides, both from the geographical point of view and the frequency of movements within the studied period. This variability is a consequence of a complex interaction among the different spatio-temporal patterns of the conditioning and triggering factors. The variability in total amount, duration and intensity of rainfall among the major 6 landsliding events is the principal cause of the difference in the number and density of landslides in each of them. However, in all 6 cases they have in common the extraordinary character of their rain values and meteorological circumstances.

\subsection{The 6 major landsliding events: meteorological conditions and seasonality}

During the analysed time span, it has been possible to define six well-known multiple landslide events on the following dates: October 1953, August 1983, July 1988, October 1992, August 2002 and November 2011.

The rainfall of October 1953 had their origin in a perturbation of frontal character, although, unlike the habitual behaviour of

145 this type of phenomena, it resembled more to a long-lasting convective storm, with very high intensity and moderate extension, similar to those usually produced by cold drops ("cut-off low") (DFG, 2006). Rainfall was mostly in a single day, reaching values much higher than $100 \mathrm{~mm} / 24$ hours and surpassing $200 \mathrm{~mm} / 24 \mathrm{~h}$ in different parts of the region (Álvarez-Usabiaga, 1983).

The cold drop of August 1983 was qualified in those days as an extraordinary phenomenon with unprecedented values in the

150 historical record, in terms of amount and intensity of rainfall, geographic extent, with a 500-year return period for the Basque Country. Although it lasted several days, data are conclusive determining that in just a few hours, the cumulative rainfall was more than half of a normal year (DFV, 1984; Pejenaute, 1991; Álvarez-Usabiaga, 1983; Capel, 1983; Fernández, 2004; Tamés et al., 1986).

The rainfall of July 18-19, 1988 was an episode also associated with a cold drop. The spatial distribution of rain was very 155 irregular, with the Deba basin being one of the most affected areas. The total rainfall occurred in a period of 2 days, but practically $89 \%$ fell in a single day. In fact, the description of this event in the National Catalogue of Historic Floods 
(http://www.proteccioncivil.es/cnih) mentions that "heavy rainfall started at 6:30 in the morning, but in only two hours 80 and $100 \mathrm{l} / \mathrm{m}^{2}$ fell on the Deba and Urola river basins".

In October 1992, the presence of cold air in the upper level of the troposphere, low surface pressures and the arrival of a very cold and unstable polar maritime air mass created a very dynamic and persistent situation that turned into a high amount of rainfall (Pejenaute, 1996). In Eibar, the closest station with complete data, $330.5 \mathrm{~mm}$ fell between October $2^{\text {nd }}$ and $12^{\text {th }}$, but 90 $\%$ had accumulated in the first 5 days. Lastur, a blind valley located in the municipality of Deba, reached $140 \mathrm{~mm} / 24$ hours (DFG, 2005).

Again, on August, 2002, the region was affected by a cold drop in which, in addition to intensity, duration was of utmost $28^{\text {th }}$ (more than $180 \mathrm{~mm}$ of cumulative rainfall), with storms that persisted more than 6 hours, especially on the $26^{\text {th }}$.

The meteorological event that originated several landslides on November 2011 was due to the existence of a cold drop in the Mediterranean Sea that generated the arrival of a northern component air mass over the Basque Country. The days $5^{\text {th }}$ and $6^{\text {th }}$ were responsible for most of the accumulated rain, exceeding $200 \mathrm{~mm}$ in Deba. The return period for this rainfall is close to 100 years (Euskalmet).

All extreme rainfall episodes described above have an evident association with the arrival of moist Atlantic airflows (sometimes topographically enhanced) combined with atmospheric upper level disturbances. Also, they show a common seasonal behaviour (summer and early autumn). This information provides evidences leading to a novel interpretation about the seasonality of the events of multiple landslide occurrences and the atmospheric conditions that generate them in northern

175 Spain, which differ from the idea maintained to the present.

According to Corominas (2006), failures in northern Spain are more frequent during winter and spring. In the same way, Valenzuela et al. (2017b), on the basis of data-covering a 35-year period, found that in Asturias landslide distribution shows a positive correlation with monthly rainfall, occurring mostly from October to April. In Vizcaya, a province bordering Deba, most of the landslides produced between 2002 and 2010, took place in autumn and winter (Díaz et al., 2012).

In Deba, as in the rest of the north coastal area of Spain, most of the annual rainfall occur in winter, due to the action of Atlantic perturbations associated with Polar Front. These meteorological situations, generally produce long-lasting rainfall, sometimes even intense, and affect a large geographical area. However, exceptional values of maximum daily rainfall are usually associated with convective systems, favoured by meridian circulation, in some cases upper level stationary disturbances ("cutoff lows"), which cause thermodynamic instability. Although they may occur at any time of the year, they are more common in summer and autumn, and most of them manifest a local character (few hundreds of $\mathrm{km}^{2}$ ) and vary substantially in intensity and duration within short distances (BOPV, 1999; DFG, 2005, 2006; Pejenaute, 2012).

It is thus clear that the long period covered in this study likely provides a representative picture of the meteorological conditions that trigger the multiple landslide events. Naturally, it is very possible that there are other landslides and even multiple landslide events that do not comply exactly with the weather patterns here described, but definitely, the events just discussed, which 
undoubtedly constitute the most significant ones (number of landslides associated with a single rainfall episode), present unambiguous signs of a certain Mediterranean-like behaviour.

\subsection{Quantitative characterization of rainfall episodes driving multiple landslides}

Once the nature of meteorological conditions associated to the 6 multiple occurrence of landslides established, it is appropriate to quantitatively determine the degree of exceptionality of those rainfall events. The rainfall amount and distribution of the 6 major rainfall episodes are illustrated in figure 2.

Based on the 3,241 rain episodes automatically computed, rainfall associated with the major landsliding events cover a quite large spectrum, in terms of both, total amount (63-280 mm) and duration (2-11 days). Figure 3a shows, for the central point, the total rainfall of the episodes without landslide activity (green dots) and the episodes that have triggered multiple landslides (red dots), as well as the curves representing the empirical percentiles, estimated over the entire 60-year period. Of the 6 major events, 5 have been associated with values of rainfall equal to or greater than $150 \mathrm{~mm}$. Although those values are generally lower than other appearing in the literature (Guzzetti et al., 2007), they are higher than the ones obtained in northern Spain. Previous studies in Asturias describe landslide initiation with $60 \mathrm{~mm}$ of cumulative rainfall, although several isolated slope instability events can even be triggered by lower rainfall values (Domínguez-Cuesta et al., 1999). Thus, although this figure seems not to be very high comparing with other geographic contexts, it is actually extraordinary in the study area. A total rainfall of $150 \mathrm{~mm}$ is only surpassed in $3 \%$ of the episodes happened between 1953 and 2015, and from them, the majority corresponds to longer episodes (up to 36 days of continuous rainfall). As can be observed, rainfall episodes without landslides show a fairly lower amount for any duration of the episode. The 6 major landsliding events correspond with rainfall values above percentile 90, being 4 of them above percentile 99.9 (2011, 1983, 1953 and 1992) and one other above percentile 99.7 (1988). This analysis shows the extraordinary nature of the rainfall storms responsible for the multiple occurrence of landslides since, as a whole, with the sole exception of August 2002, they are among the $1 \%$ of the rainiest episodes in the area for the last 60 years.

Concerning intensity, figure $3 \mathrm{~b}$ represents I-D values of all rain episodes (computed for the central point). Regardless of the duration, the intensity of the 6 rain episodes associated with multiple landslides is among the highest of the 3,241 episodes and higher than those of no landslide activity. On the contrary, the rain episodes that coincide with periods of undetermined landslide activity (Table 1) are in general lower and likely have produced landslides but of uncertain date of occurrence. In conclusion, although all of them are extreme, the multiple landslide events show important differences, both in the number of movements and in the amount and intensity of rainfall that triggered them; the 2002 event is clearly lower, since it was a quite long event of relatively low daily intensity, not exceeding $39 \mathrm{~mm}$ any day.

220 In order to validate the extraordinary nature of the rainfall values obtained, the antecedent rainfall was aggregated (Fig. 3c). Symbols in the figure match the 6 major landsliding events identified, accumulating rainfall up to the previous 13 days, 1-14, before landslide occurrence (the figure only shows a part of the computed antecedent rainfall, up to 28 days). Lines show 
empirical percentiles of rainfall. As can be seen, 3 of the 6 major events (1953, 1983 and 1992) constitute the most extreme events of the entire 60-year series, in 2 to 5 days of rainfall. The most extreme case corresponds to the 1983 episode, which represents the maximum rainfall accumulated in 2, 3, 4, 5 and 6 days of the period analysed. Other not so extreme events (1988 and 2002) also exceed 99 percentile (1988: 1 day of previous rainfall; 2002: 6-7 days of previous rainfall) for some duration. Thus, the rainfall responsible for more than $50 \%$ of the landslides (688 from 1,180 landslides) in the municipality of Deba is within the $1 \%$ of the most extreme rainfall episodes.

The three alternative analyses confirm again the extreme nature of the storms that have caused multiple landslides in the recent past.

\subsection{I-D rainfall threshold functions}

A quantitative correlation between rain intensity and duration can be established, obtaining a tentative I-D threshold function (Fig. 4). Although the use of daily rainfall records is not the most recommendable, is acceptable for defining regional thresholds. However, the lack of hourly rainfall data led to underestimate the rainfall needed to trigger multiple landslides and will inevitably affect the accuracy of thresholds. Despite of the fact that rainfall data is daily, duration has been expressed in hourly units to better compare with other functions described in literature.

A power law curve is assumed: $\mathrm{I}=\alpha \mathrm{D}^{-\beta}$, where $\mathrm{I}$ is the rainfall mean intensity $(\mathrm{mm} / \mathrm{h})$ and $\mathrm{D}$ is the duration. In a $\log \mathrm{I}$ vs. $\log \mathrm{D}$ plot, $\alpha$ is the intercept and $\beta$ defines the slope of the power function. The I-D data shows the usual descending trend of the minimum amount of average rainfall intensity needed to initiate the mass movements with increasing rainfall duration. The fitted line has been shifted downward until it low-bound all multiple landslides identified (lower envelope function). The I-D function provided in this study represents the lower limit corresponding to the 6 major events that imply the occurrence of multiple shallow landslides. It refers exclusively to extreme conditions that enable the simultaneously occurrence of a large number of slope movements.

245 The resulting function is $\mathrm{I}=7.7 \mathrm{D}^{-0.428}$ (Fig. 4). Therefore, any event exceeding that lower envelope could be considered as a trigger of multiple slides and, consequently, warning could be contemplated. This I-D function makes it possible to determine the relative importance of intensity and duration in multiple landslide occurrence, as regards the climatic context of the study area and the type of slope movement. According to Guzzetti et al. (2008) in mild marine west-coast climate of mid-latitude region, rainfall duration is more important than intensity to initiate shallow slope failures, compared to areas of Mediterranean climate or even mountain areas where the intensity is more relevant. Secondly, shallow movements are usually related to short intense storms, while most deep-seated landslides are commonly triggered by rainfall periods lasting from several weeks to several months (Wieczorek, 1987; Corominas et al., 2002; Zezere and Rodrigues, 2002; Marques et al., 2008), or even by longterm variation of annual rainfall (Aleotti, 2004). Also, episodes of multiple and widespread landslides are more probable with longer rainfall periods (Guzetti et al., 2007, 2008). Thereby, multiple occurrence of landslides in Deba should be linked to 
intense long-term rainfall. Intense rain is necessary for the triggering of shallow landslides and long duration is determinant for the multiple occurrence. The obtained rainfall I-D function (-0.4 exponent) is coherent with that statement.

I-D function thus obtained provides a standard format, which allows comparisons with other functions found by other authors and/or in other places with similar environmental conditions. The results presented by Guzzetti et al. (2007, 2008), from tens of rainfall thresholds worldwide, suggest that those local are usually slightly higher than regional, and higher than global ones, due to an effect of the spatial scale. As a result, in equal conditions, it would be reasonable for our threshold to be higher than others of the ensemble (Fig. 4). The threshold obtained in this work, with a very local character, is higher than the globalregional ones associated with shallow landslides, provided by Guzzetti et al. (2008) $\left(\mathrm{I}=2.28 \mathrm{D}^{-0.20} ; \mathrm{I}=0.48 \mathrm{D}^{-0.11}\right)$, for episodes above and below 48 hours, respectively. It is also worth comparing the threshold obtained with closer examples, of a local or regional origin, such as the figures published for the Pyrenees and Asturias, in northern Spain (Fig. 4).

265 For the Eastern Pyrenees, Corominas et al. (2005) established a regional I-D threshold to initiate mass movements in low permeability clays, applicable to events of rainfall longer than 165 hours. The threshold reported ( $\mathrm{I}=17.96 \mathrm{D}^{-0.59}$ ) is comparatively high, but it must be considered that it refers not only to shallow landslides and that there are significant differences with the study area of this work, in terms of lithology, land use and climate.

On the contrary, Asturias does correspond to the same climate, although with some differences in the type of movement, environmental conditions (geomorphological and geological) and time periods covered, which could justify the found discrepancies. Valenzuela et al. (2017a), estimated regional minimum thresholds from 2 major landsliding events occurred in 2008 and 2010. One threshold corresponds to an episode of short duration and intense rainfall $\left(\mathrm{I}=44.89 \mathrm{D}^{-0.80}\right)$, while the other is related to a low-intensity and long-duration event $\left(\mathrm{I}=0.70 \mathrm{D}^{-0.25}\right)$. While in Asturias the threshold is obtained jointly for all types of landslides, shallow and deep, including those produced in road slopes, the threshold in Deba only represents shallow landslides produced in natural slopes. It is then straightforward that the conditions that control their triggering are not comparable.

Overall, it is necessary to remark that the landslides analysed in Deba cover a total of 60 years, a more representative time span, while the periods studied in Asturias and the Pyrenees are much more limited. Likewise, in Deba, other landslides occur under less extreme rainfall conditions. Again, the lower boundary threshold here obtained does not refer to the minimum I-D rainfall conditions required to initiate a landslide but the rainfall capable of producing multiple landslide occurrences.

In order to improve the I-D thresholds, especially for warning system purposes, it would be advisable to apply validation approaches, that allow to assess the level of uncertainty and the confidence levels of the prediction and forecasts (Guzzetti et al., 2008; Chang and Chiang, 2009; Brunetti et al., 2010; Berti, 2012; Peruccacci et al., 2012; Melillo et al., 2016).

285 Nevertheless, the application of probabilistic approaches is not the most reasonable with the empirical data sets at hand. An updated database, with a greater number of new events, or independent databases for close areas, would be very useful to test the results obtained in Deba. 


\section{Conclusions}

290 Landslides occurrence in Deba (NW of Guipúzcoa, Spain) during the last 60 years have been analysed concerning their main causal agent: extreme rainfall. The study covers a much broader period than other previous works in northern Spain and refers exclusively to shallow landslides developed on natural slopes, the most frequent in the region.

Six major rainfall episodes causing multiple landslide occurrence (> $50 \%$ of the 1,180 slope movements inventoried), have been identified and analysed. The extraordinary rainfall responsible of those events have been characterised and quantified,

295 applying 3 different strategies.

The quantitative analysis of the rainfall episodes driving multiple landslides shows that they are extraordinary in both quantity and intensity. An I-D threshold function has been obtained, which represents a minimum rainfall value necessary for generating multiple landslides simultaneously. This local function has been compared with other described in close areas, despite the differences on the type of process, terrain and climate. The 3 different strategies of analysis validate the results.

300 The meteorological conditions associated to these events have revealed a clear relationship with stormy phenomena (convective origin), characterized by rainy spells of especially high intensity, short duration, for the climatic context of the area, and relatively local dimension. This type of situation is especially frequent in summer and early autumn seasons, showing a behaviour more characteristic of the Mediterranean area.

In spite of the existing uncertainties and the subsequent limitations of the results, the better knowledge of the influence of 305 rainfall in the study area will be useful to improve the predictions of this type of processes. In this way, these results constitute a significant improvement in the geomorphological knowledge about the landslide process in the study area and the rainfall triggering conditions, all of which can be very useful to make hazard predictions.

\section{Acknowledgements}

310 This investigation has been supported by the research projects: ESPERIDES (CGL2013-46425-P; MINECO, Spain) and “Influencia del cambio climático y de la actividad humana en los procesos y riesgos geomorfológicos” (29.P052.64004, UC).

\section{References}

Aleotti, P.: A warning system for rainfall-induced shallow failures. Engineering Geology, 73, 247-265, 315 https://doi.org/10.1016/j.enggeo.2004.01.007, 2004.

Álvarez-Usabiaga, J.I.: Informe técnico elaborado por el Centro Meteorológico Zonal de San Sebastián sobre las precipitaciones registradas durante los días 26 y 27 de agosto de 1983 en el área geográfica dependiente de este centro, Centro Meteorológico Zonal, San Sebastián, 1983. 
Berti, M., Martina, M. L. V., Franceschini. S., Pignone, S., Simoni, A. and Pizziolo, M.: Probabilistic rainfall thresholds for landslide occurrence using a Bayesian approach, Journal of Geophysical Research, 117, F04006, https://doi.org/10.1029/2012JF002367, 2012.

Bonachea, J., Remondo, J., Díaz de Terán, J. R., González-Díez, A. and Cendrero, A.: Landslide risk models for decision making. Risk Analysis, 29, 1629-1643, https://doi.org/10.1111/j.1539-6924.2009.01283.x, 2009.

BOPV (Boletín Oficial del País Vasco): Suplemento al n. ${ }^{\circ} 153$ jueves 12 de agosto de 1999. RESOLUCIÓN 15/1999, de 15 de junio, del Director de la Secretaría del Gobierno y de Relaciones con el Parlamento por la que se dispone la publicación del Acuerdo del Consejo de Gobierno por el que se aprueba el Plan Especial de Emergencias ante el Riesgo de Inundaciones de la Comunidad Autónoma del País Vasco, 1999.

Brunetti, M. T., Peruccacci, S., Rossi, M., Luciani, S., Valigi, D. and Guzzetti, F.: Rainfall thresholds for the possible occurrence of landslides in Italy, Nat. Hazards Earth Syst. Sci. 10, 447-458, https://doi.org/10.5194/nhess-10-447, 2010.

330 Caine, N.: The rainfall intensity-duration control of shallow landslides and debris flows, Geografisker Annaler Series A, 62, 23-27, https://doi.org/10.2307/520449, 1980.

Capel, J. J.: El clima de la España Cantábrica: las inundaciones de agosto de 1983 en el País Vasco, Cantabria y Navarra atlántica, La Crónica, Almería, 1983.

Chang, K. T. and Chiang, S.H.: An integrated model for predicting rainfall-induced landslides, Geomorphology, 105 (3), $366-$

335 373, https://doi.org/10.1016/j.geomorph.2008.10.012, 2009.

Corominas, J.: Landslides and climate. Keynote Lectures from 8th International Symposium on Landslides, 4, 1-33, 2001.

Corominas, J.: El clima y sus consecuencias sobre la actividad de los movimientos de ladera en España, Cuaternario y Geomorfología, 20 (3-4), 89-113, 2006.

Corominas, J. and Moya, J.: Reconstructing recent landslide activity in relation to rainfall in the Llobregat River basin Eastern

340 Pyrenees Spain, Geomorphology, 30, 79-93, https://doi.org/10.1016/S0169-555X(99)00046-X, 1999.

Corominas, J., Moya, J. and Hürlimann, M.: Landslide rainfall triggers in the Spanish eastern Pyrenees, Proceedings of the 4th EGS Plinius Conference held at Mallorca, Spain, 2002.

Corominas, J., Ayala, F. J., Cendrero, A., Chacón, J., Díaz de Terán, J. R., González, A., Moya, J. and Vilaplana, J. M.: Riesgo de inestabilidad de laderas. In Evaluación Preliminar de los Impactos en España por Efecto del Cambio Climático. Proyecto 345 ECCE, Moreno JM (coord.), Ministerio de Medio Ambiente, Madrid, 549-579, 2005.

Crozier, M.: Prediction of rainfall triggered landslides: a test of the antecedent water status model, Earth Surf. Process. Landforms, 24, 825-833, 1999.

Crozier, M.: Multiple occurrence regional landslide events in New Zealand: hazard management issues, Landslides, 2, 247256, https://doi.org/10.1007/s10346-005-0019-7, 2005.

350 Díaz, E., Sáenz de Olazagoitia, A., Ormaetxea, O. and Ibisate, A.: Análisis de factores de desestabilización de laderas en dos cuencas del ámbito atlántico: Sollube-Mape (Bizkaia) y Ramaio (Alava), Cuaternario y Geomorfología, 26 (1-2), 171-190, 2012. 
DFG (Diputación Foral de Guipúzcoa): Estudio de precipitaciones intensas, tiempos de concentración y caudales de cálculo de las cuencas del territorio histórico de Guipúzcoa y estudio de actualización, Unpublished report, 2005.

DFG (Diputación Foral de Guipúzcoa): Bases para la elaboración de las directrices sobre el uso sostenible del agua en Guipúzcoa: Caracterización de las situaciones Hidrológicas extremas en Guipúzcoa y situación frente a inundaciones en Guipúzcoa. Departamento para el desarrollo Sostenible, Dirección General de Obras Hidráulicas, 56 pp., 2006.

DFV (Diputación Foral de Vizcaya) Lluvias torrenciales, agosto 1983: cuantificación de la catástrofe, 261 pp., 1984.

Domínguez-Cuesta, M. J., Jiménez-Sanchez, M. and Rodríguez-García, A: Press archives as temporal records of landslides in the North of Spain: relationships between rainfall and instability slope events, Geomorphology, 30, 125-132, 1999.

Euskalmet, Climatología año a año, http://www.euskalmet.euskadi.eus/s075853x/es/contenidos/informacion/cli_2011/es_clieus/es_2011.html, last access: 8 May 2016.

Fernández, P. C.: Las inundaciones en Euskadi de 1983, http://www.tiempo.com/ram/1354/lasinundacioneseneuskadide1983/, last access: 28 April 2014.

365 Garcia-Urquía, E.: Establishing rainfall frequency contour lines as thresholds for rainfall-induced landslides in Tegucigalpa, Honduras, 1980-2005, Natural Hazards, 82, 2107-2132, https://doi.org/10.1007/s11069-016-2297-x, 2016.

Glade, T., Crozier, M. and Smith, P.: Applying probability determination to refine landslide triggering rainfall thresholds using an empirical “antecedent daily rainfall model”, Pure Applied Geophysics, 157, 1059-1079, https://doi.org/10.1007/s000240050017, 2000.

370 Guzzetti, F., Peruccacci, S., Rossi, M. and Stark, C. P.: Rainfall thresholds for the initiation of landslides in central and southern Europe, Meteorol. Atmos. Phys., 98, 239-267, https://doi.org/10.1007/s0070300702627, 2007.

Guzzetti, F., Peruccacci, S., Rossi, M. and Stark, C. P.: The rainfall intensity-duration control of shallow landslides and debris flows: an update, Landslides, 5, 3-17, https://doi.org/10.1007/s10346-007-0112-1, 2008.

Li, C., Ma, T., Zhu, X. and Li, W.: The power-law relationship between landslide occurrence and rainfall level, Geomorphology, 130 (3), 221-229, https://doi.org/10.1016/j.geomorph.2011.03.018, 2011.

Ma, T., Li, C., Lu, Z. and Wang, B.: An effective antecedent precipitation model derived from the power-law relationship between landslide occurrence and rainfall level, Geomorphology, 216, 187-192, https://doi.org/10.1016/j.geomorph.2014.03.033, 2016.

Marques, R., Zézere, J., Trigo, R., Gaspar, J. and Trigo, I.: Rainfall patterns and critical values associated with landslides in Povoação County (Sao Miguel Island, Azores): relationships with the North Atlantic Oscillation, Hydrol. Process., 22, 478494, https://doi.org/10.1002/hyp.6879, 2008.

Martelloni, G., Segoni, S., Fanti, R. and Catani, F.: Rainfall thresholds for the forecasting of landslide occurrence at regional scale, Landslides, 9, 485-495, https://doi.org/10.1007/s10346-011-0308-2, 2012.

Mateos, R. M., García-Moreno, I. and Azañón, J. M.: (2012) Freeze-thaw cycles and rainfall as triggering factors of mass movements in a warm Mediterranean region: the case of the Tramuntana Range (Majorca, Spain), Landslides, 9, 417-432, https://doi.org/10.1007/s10346-011-0290-8, 2012. 
https://doi.org/10.5194/nhess-2019-416

Preprint. Discussion started: 21 February 2020

(c) Author(s) 2020. CC BY 4.0 License.
Natural Hazards

and Earth System

Sciences

Discussions

Melillo, M., Brunetti, M. T., Peruccacci, S., Gariano, S. L. and Guzzetti, F.: Rainfall thresholds for the possible landslide occurrence in Sicily (Southern Italy) based on the automatic reconstruction of rainfall events, Landslides, 13, 165-172, https://doi.org/10.1007/s10346-015-0630-1, 2016.

Palladino, M. R., Viero, A., Turconi, L., Brunetti, M. T., Peruccacci, S., Melillo, M., Luino, F., Deganutti, A. M. and Guzzetti, F.: Rainfall thresholds for the activation of shallow landslides in the Italian Alps: the role of environmental conditioning factors, Geomorphology, 303, 53-67, https://doi.org/10.1016/j.geomorph.2017.11.009, 2018.

Pejenaute J. M.: Estudio de las precipitaciones torrenciales de agosto de 1983 en Navarra, Lurralde, 14, 117-129, 1991.

Pejenaute J. M.: Estudio de un episodio de lluvia torrencial en Navarra con efectos de inundación, Espacio, Tiempo y Forma, 395 Serie VI, Geografía 9, 133-177, 1996.

Pejenaute J. M.: Influencia de los factores geográficos en las inundaciones de los valles cantábricos navarros, Territoris, 8, 193-211, 2012.

Peruccacci, S., Brunetti, M.T., Luciani, S., Vennari, C. and Guzzetti, F.: Lithological and seasonal control on rainfall thresholds for the possible initiation of landslides in central Italy, Geomorphology, 140, 79-90,

400 https://doi.org/10.1016/j.geomorph.2011.10.005, 2012.

Peruccacci, S., Brunetti, M. T., Gariano, S. L., Melillo, M., Rossi, M. and Guzzetti, F.: Rainfall thresholds for possible landslide occurrence in Italy, Geomorphology, 290, 39-57, https://doi.org/10.1016/j.geomorph.2017.03.031, 2017.

Reichenbach, P., Cardinali, M., De Vita, P. and Guzzetti, F.: Regional hydrological thresholds for landslides and floods in the Tiber River Basin (central Italy), Environmental Geology, 35 (2-3), 146-159, 1998.

405 Remondo, J., Gonzalez, A., Díaz de Terán, J. R., Cendrero, A., Fabbri, A. and Chung, C. J.: Validation of Landslide Susceptibility Maps; examples and applications from a case study in Northern Spain, Natural Hazards, 30 (3), 437-449, https://doi.org/10.1023/B:NHAZ.0000007201.80743.fc, 2003a.

Remondo, J., Gonzalez, A., Díaz de Terán, J. R. and Cendrero, A.: Landslide susceptibility models utilising the Lower Deba Valley, Guipúzcoa (Spain), Natural Hazards 30 (3), 267-279, https://doi.org/10.1023/B:NHAZ.0000007202.12543.3a, 2003b.

410 Remondo, J., Bonachea, J. and Cendrero, A.: A statistical approach to landslide risk modelling at basin scale; from landslide susceptibility to quantitative risk assessment, Landslides, 2, 321-328, https://doi.org/10.1007/s10346-005-0016-x, 2005.

Remondo, J., Bonachea, J. and Cendrero, A.: Quantitative landslide risk assessment and mapping on the basis of recent occurrences, Geomorphology, 94, 495-507. https://doi.org/10.1016/j.geomorph.2006.10.041, 2008

Remondo, J., Bonachea, J., Rivas, V., Sánchez-Espeso, J., Bruschi, V. M., Cendrero, A., Díaz de Terán, J. R., Fernández-

415 Maroto, G., Gómez-Arozamena, J., González-Díez, A. and Sainz, C.: Landslide hazard scenarios based on both past landslides and precipitation, in Advancing Culture of Living with Landslides 2, edited by: Mikos, M., Tiwari, B., Yin, Y. and Sassa, K., Springer, Berlin, Heidelberg, Germany, 981-988, https://doi.org/10.1007/978-3-319-53498-5_111, 2017.

Rivas, V., Remondo, J. and Bonachea, J.: Análisis de las relaciones entre precipitación y actividad de deslizamientos en el pasado reciente (NO Guipúzcoa), Geotemas, 16 (1), 633-636, 2016. 
420 Segoni, S., Piciullo, L. and Gariano, S.L.: A review of the recent literature on rainfall thresholds for landslide occurrence. Landslides, https://doi.org/10.1007/s10346-018-0966-4, 2018.

Tamés, P., Elosegui, J.M., Salazar, A., Almoguera, J., Albert, J., Solesio, J., Fernández Areces, J.L. and López Vilchez, L.: Estudio de riesgos naturales del territorio de Guipúzcoa (2 $2^{\mathrm{a}}$ fase). Términos municipales de Deba, Motrico, Mendaro, Elgoibar y Eibar, 5 Vols., Diputación Foral Guipúzcoa, Open file report, 1986.

425 Valenzuela, P., Dominguez-Cuesta, M. J., Mora-García, M. and Jiménez-Sánchez, M.: Rainfall thresholds for the triggering of landslides considering previous soil moisture conditions (Asturias, NW Spain), Landslides, 15 (2), 273-282, https://doi.org/10.1007/s10346-017-0878-8, 2017a.

Valenzuela, P., Dominguez-Cuesta, M. J., Mora-García, M. and Jiménez-Sánchez, M.: A spatio-temporal landslide inventory for the NW of Spain: BAPA database, Geomorphology, 293, 11-23, https://doi.org/10.1016/j.geomorph.2017.05.010, 2017b.

430 Wieczorek, G. F.: Effect of rainfall intensity and duration on debris flows in central Santa Cruz Mountains, California, in: Debris flows/avalanches: Process, recognition and mitigation, edited by: Costa, J. E. and Wieczorek, G. F., Geological Society of America, Reviews in Engineering Geology, 7, 93-104, 1987.

Zêzere, J. L. and Rodrigues, M. L.: Rainfall thresholds for landsliding in Lisbon area (Portugal), in Landslides, edited by: Rybar, J., Stemberk, J. and Wagner, P., AA. Balkema, Lisse, 333-338, 2002.

435 Zêzere, J. L., Vaz, T., Pereira, S., Oliveira, S. C., Marques, R. and Garcia, R. A. C.: Rainfall thresholds for landslide activity in Portugal: a state of the art, Environmental Earth Sciences, 73 (6), 2917-2936, https://doi.org/10.1007/s12665-014-3672-0, 2015.

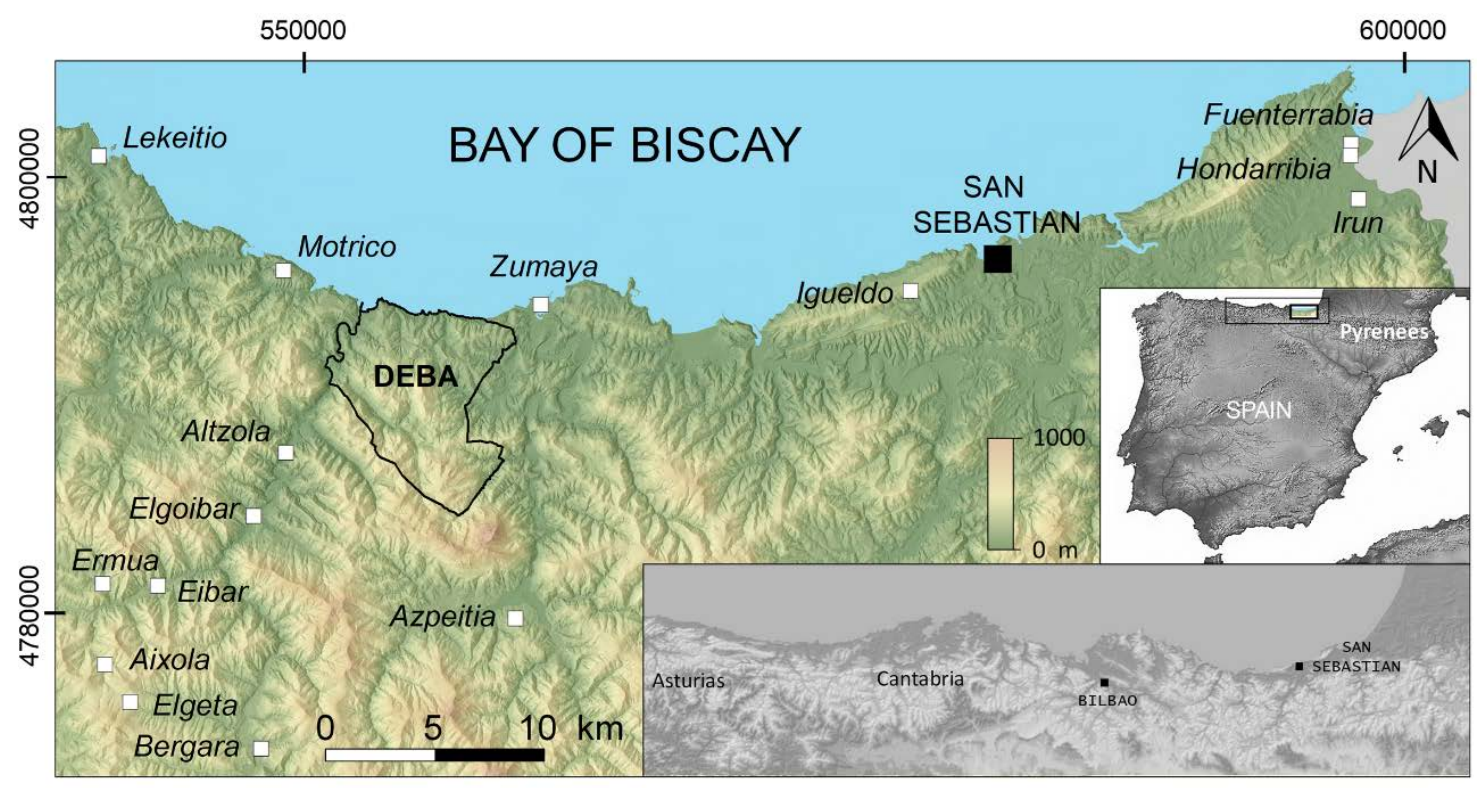

440 Figure 1. Study area location (Deba), weather stations (white squares) and places mentioned in the text. 

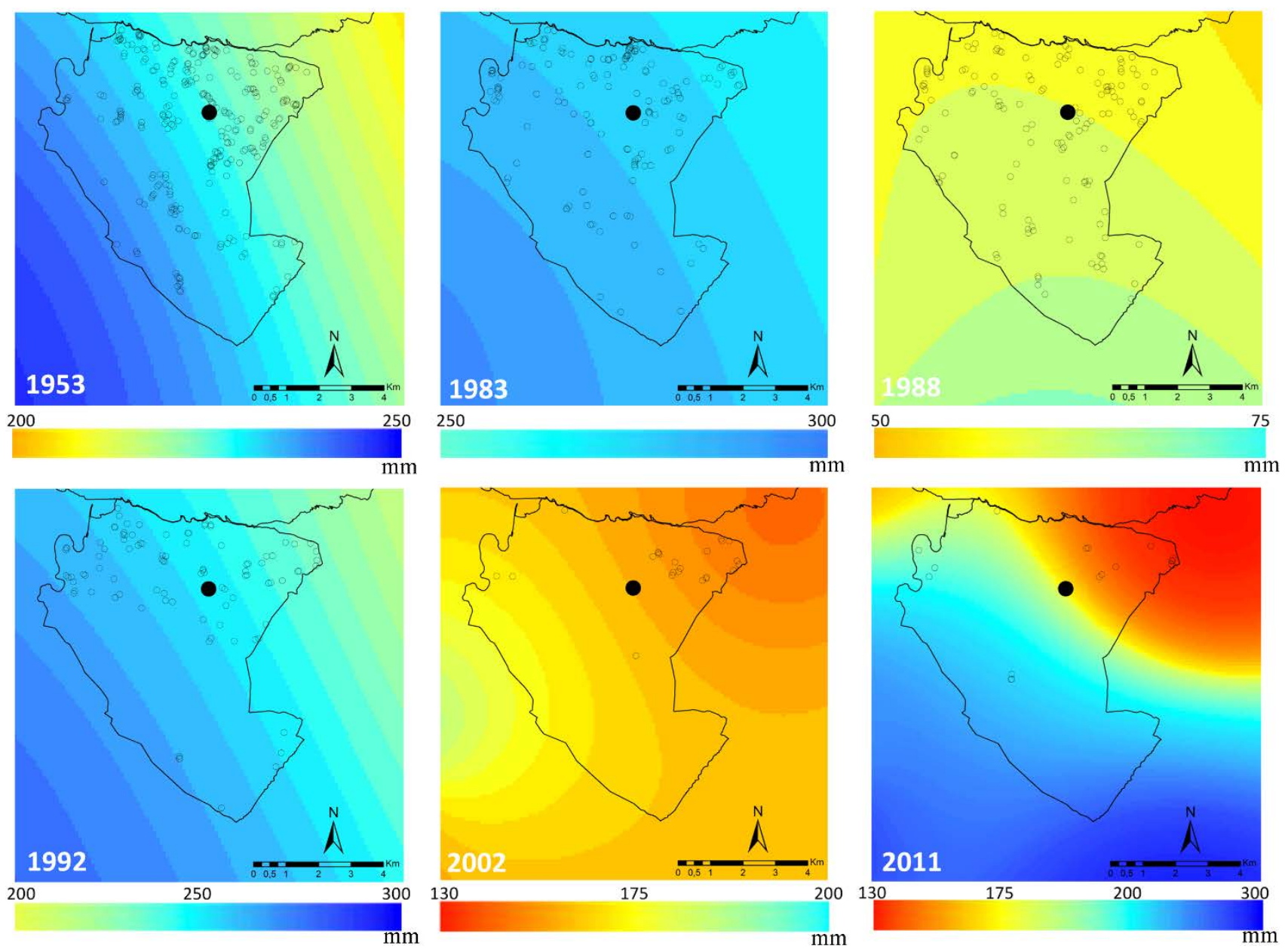

Figure 2. Rainfall patterns of the 6 major rainfall episodes responsible of causing multiple landslides. Landslides produced by each episode are also represented. Total amount of rainfall $(\mathrm{mm})$ associated to each movement is shown; the colour scale has been adapted to facilitate visualization. The black central point corresponds to the location for which rainfall has been automatically estimated. 
https://doi.org/10.5194/nhess-2019-416

Preprint. Discussion started: 21 February 2020

(c) Author(s) 2020. CC BY 4.0 License.

a

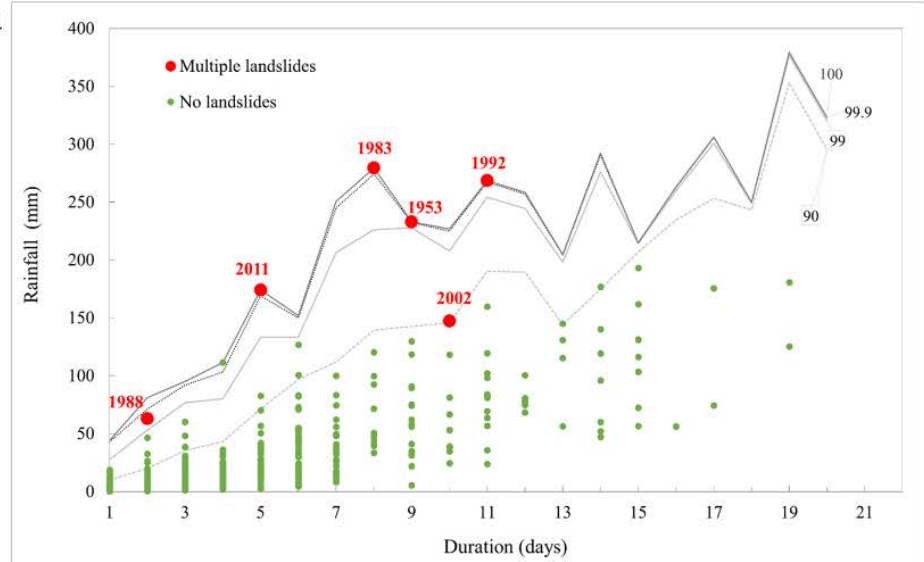

b

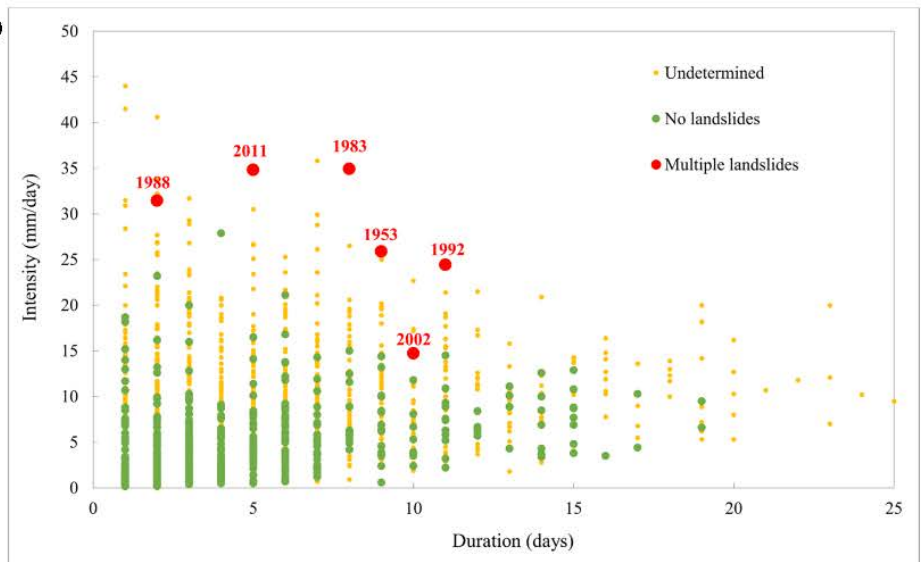

c

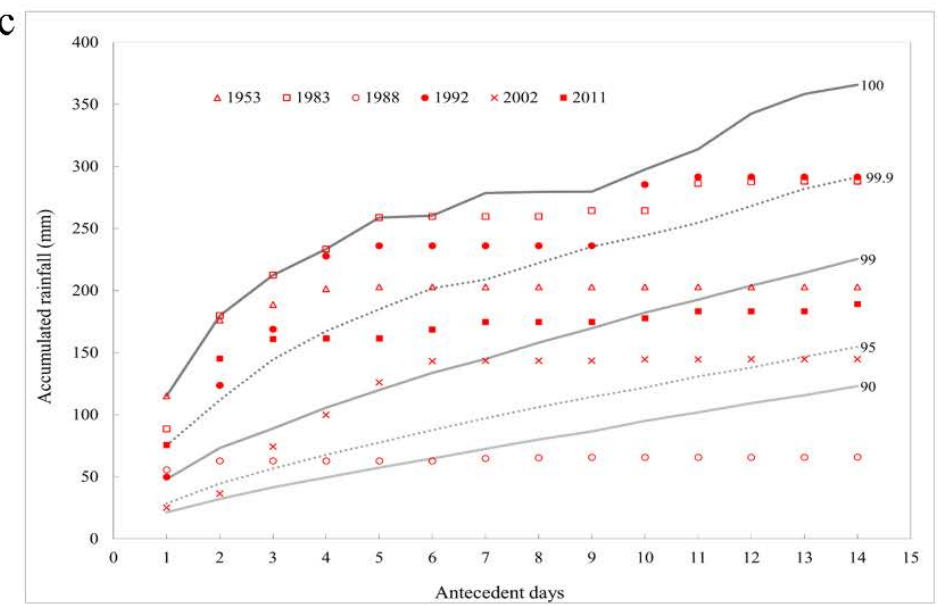

Figure 3. Quantitative characterization of rainfall episodes with multiple landslides. a: Rainfall amount and duration of the episodes automatically defined (only multiple landslide occurrence events, red, and no-landslide activity periods, green, are presented). Lines correspond to empirical percentiles, based on the 3,241 rainfall episodes. b: I-D values for all the 3,241 rainfall episodes occurred from 1953 to 2015 for a central and representative point in the area. c: Aggregation of 1-13 daily antecedent rainfall empirical percentiles. Symbols correspond to the 6 major landsliding events. 
https://doi.org/10.5194/nhess-2019-416

Preprint. Discussion started: 21 February 2020

(c) Author(s) 2020. CC BY 4.0 License.

(c) (i)
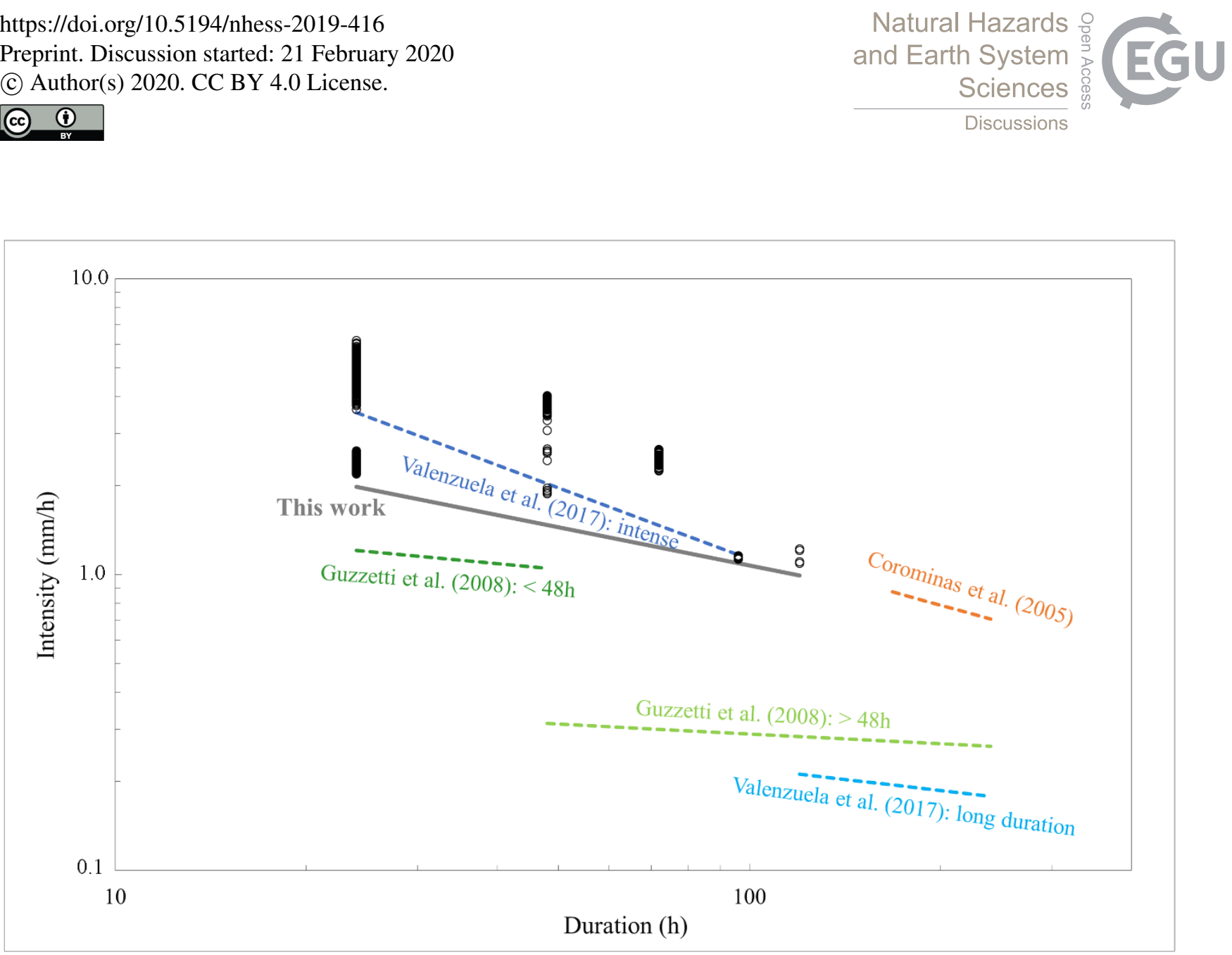

Figure 4. I-D rainfall function obtained in this work and comparison with thresholds of other authors referenced in the text. Black circles represent I-D values for the 688 dated landslides. 
Table 1. Periods of landslide activity. Characteristics of the images used for the inventory of landslides.

\begin{tabular}{|c|c|c|c|c|c|}
\hline Type & Flight date & $\begin{array}{c}\text { Scale/ } \\
\text { Resolution }\end{array}$ & Colour/BW & $\begin{array}{c}\text { No. } \\
\text { landslides } \\
\text { identified }\end{array}$ & $\begin{array}{c}\text { Landslide } \\
\text { activity }\end{array}$ \\
\hline Ortophoto & 21/June-30/June, 2015 & $25 \mathrm{~cm}$ & Colour & 3 & No \\
\hline Ortophoto & 16/July-03/October, 2014 & $25 \mathrm{~cm}$ & Colour & 3 & No \\
\hline Ortophoto & 30/July-04/September, 2013 & $25 \mathrm{~cm}$ & Colour & 8 & Undetermined \\
\hline Ortophoto & 23/July-08/August, 2012 & $25 \mathrm{~cm}$ & Colour & 18 & Multiple \\
\hline Ortophoto & 19/June-25/June, 2011 & $25 \mathrm{~cm}$ & Colour & 1 & No \\
\hline Ortophoto & 04/June-01/July, 2010 & $25 \mathrm{~cm}$ & Colour & 9 & Undetermined \\
\hline Ortophoto & 23/April-29/May, 2009 & $25 \mathrm{~cm}$ & Colour & 5 & Undetermined \\
\hline Ortophoto & 27/July-06/October, 2008 & $25 \mathrm{~cm}$ & Colour & 6 & Undetermined \\
\hline Ortophoto & 17/March-06/September, 2007 & $50 \mathrm{~cm}$ & Colour & 0 & No \\
\hline Ortophoto & 17/July-14/November, 2006 & $25 \mathrm{~cm}$ & Colour & 9 & Undetermined \\
\hline Ortophoto & 02/June/-15/July, 2005 & $50 \mathrm{~cm}$ & Colour & 0 & No \\
\hline Ortophoto & 15/July-28/September, 2004 & $25 \mathrm{~cm}$ & Colour & 4 & No \\
\hline Ortophoto & 10/September-29/September, 2002 & $25 \mathrm{~cm}$ & Colour & 23 & Multiple \\
\hline Ortophoto & 1/September-30/September, 2001 & $1 \mathrm{~m}$ & Colour & 8 & No \\
\hline Aerial Photo & 3-4 April, 1997 & $1 / 18000$ & Colour & 223 & Undetermined \\
\hline Aerial Photo & April-August, 1993 & $1 / 15000$ & Colour & 95 & Multiple \\
\hline Aerial Photo & March, 1991 & $1 / 18000$ & Colour & 133 & Multiple \\
\hline Aerial Photo & June-September, 1985 & $1 / 15000$ & BW & 141 & Multiple \\
\hline Aerial Photo & May-June, 1983 & $1 / 18000$ & BW & 104 & Undetermined \\
\hline Aerial Photo & No Data, 1970 & $1 / 15000$ & BW & 109 & Undetermined \\
\hline Aerial Photo & January, 1954 & $1 / 12000$ & BW & 278 & Multiple \\
\hline
\end{tabular}

